\title{
PENULIS SUNDA SEBAGAI PELESTARI BUDAYA
}

\author{
Santi Susanti, Deddy Mulyana, Ninis Agustini Damayani \\ Fakultas Ilmu Komunikasi Universitas Padjadjaran \\ Jl. Raya Bandung Sumedang km 21, Jatinangor, Sumedang \\ Email: santisusanti2202@gmail.com
}

\begin{abstract}
This research aims to find out motives to become Sundanese Writers, self meaning construction of Sundanese Writers as culture preservators and message presenting process of Sundanese Writers as culture preservators. This research used qualitative method with a phenomenological approach. Data was gained through a series of indepth interviews with eight informants as Sundanese Writers in Bandung City, and also from nonparticipant observation and literature study. The informants of this research are classified into two types, these are Sundanese Culture Inheritors and Sundanese Culture Developers. The results of this study indicated that the main motive to become a Sundanese Writers is idealism, which consists of aspects of driving and the aspects of expectation. The self meaning of Sundanese Writers as culture preservators was constructed into two types, these are Sundanese Culture Inheritors and Sundanese Culture Developers. Message presenting process of Sundanese Writers as culture preservators were done by involving steps commonly done by writers to produce a writing.
\end{abstract}

\section{PENDAHULUAN}

Salah satu bagian keberagaman budaya di Indonesia adalah budaya Sunda yang tumbuh dan berkembang di Jawa Barat atau dikenal sebagai Tatar Pasundan. Hasil dari budaya tersebut, salah satunya adalah Bahasa Sunda yang digunakan sebagian besar penduduk Jawa Barat, termasuk di Kota Bandung. Dalam kondisi saat ini, terdapat kekhawatiran dari berbagai pihak akan punahnya bahasa daerah termasuk
Key words: Communication, Sundanese Writers, Culture Preservators

ABSTRAK- Penelitian ini bertujuan menemukan motif menjadi Penulis Sunda, konstruksi makna diri Penulis Sunda sebagai pelestari budaya dan proses penyampaian pesan Penulis Sunda sebagai Pelestari Budaya. Metode penelitian yang digunakan adalah kualitatif dengan pendekatan studi fenomenologi. Data diperoleh melalui wawancara mendalam dengan delapan Penulis Sunda yang berada di Kota Bandung, juga melalui observasi nonpartisipan dan studi pustaka. Hasil penelitian ini mengungkapkan bahwa motif utama menjadi Penulis Sunda adalah idealisme kesundaan, yang terbagi ke dalam aspek pendorong dan aspek harapan. Konstruksi makna diri Penulis Sunda sebagai pelestari budaya terbagi menjadi Pewaris Budaya Sunda dan Pengembang Budaya Sunda. Proses penyampaian pesan Penulis Sunda sebagai Pelestari Budaya dilakukan melalui tahapan yang umum dilakukan penulis untuk menghasilkan suatu tulisan.

Kata kunci: Komunikasi, Penulis Sunda, Pelestari Budaya

Bahasa Sunda, yang penggunanya terus berkurang akibat perkembangan zaman yang mengikis kecintaan terhadap bahasa daerah.

Pada Bahasa Sunda, empat puluh persen masyarakat Jawa Barat dikabarkan tidak bisa menggunakan Bahasa Sunda (Koran Tempo, 22/2/2008) dan di Kota Bandung, diperkirakan penggunanya tinggal 30 persen, itupun terbatas pada siswa-siswa sekolah yang belajar Bahasa Sunda (Pikiran 
Rakyat, 15/2/2007). Di kota besar seperti Bandung, kekhawatiran tersebut beralasan, karena, semakin banyak orang tua, terutama ibu-ibu muda yang tidak mau menggunakan Bahasa Sunda dalam percakapan sehari-hari, karena Bahasa Sunda dianggap tidak intelek, tidak sesuai dengan kebutuhan teknologi. Malah banyak orang tua yang melarang anaknya menggunakan Bahasa Sunda karena takut Bahasa Sundanya kasar. Akibatnya, banyak orang Sunda yang lebih memilih menggunakan Bahasa Indonesia daripada Bahasa Sunda sehingga Bahasa Sunda menjadi bahasa kedua setelah Bahasa Indonesia (Pikiran Rakyat, 15/2/2007)

Berkurangnya jumlah pengguna Bahasa Sunda ini, berimbas pula pada minat baca terhadap karya tulis dan media massa berbahasa Sunda. Penyebabnya, karena tidak mengerti artinya sehingga memilih meninggalkan terbitan berbahasa Sunda. Umumnya, pembaca setia media berbahasa Sunda adalah para sepuh yang sudah lama berlangganan media tersebut. Kondisi minimnya minat baca terhadap terbitan berbahasa Sunda ini berimbas pada banyaknya karya yang dihasilkan oleh para Penulis Sunda. Direktur Penerbit Geger Sunten, sekaligus Penulis Sunda, Taufik Faturohman mengatakan, dalam lima tahun terakhir jumlah terbitan fiksi berbahasa Sunda semakin berkurang, dari 20 judul menjadi lima judul per tahun. Menurut
Taufik, penurunan ini dipicu oleh kurangnya pembaca, sehingga royalti didapat dalam waktu lama. Dari satu buku berbahasa Sunda yang dicetak 2.000 eksemplar, royalti yang didapat hanya $R p 1$ juta-Rp 2 juta dalam waktu tiga tahun (Kompas, 14/2/2010).

Meski demikian, masih ada para penulis yang konsisten membangun komunikasi dengan pembacanya melalui tulisan tentang kesundaan, yang ditulis dalam Bahasa Sunda maupun Bahasa Indonesia. Para penulis ini memanfaatkan media yang tersedia, yaitu media cetak (majalah, surat kabar dan buku) dan online (blog dan website) untuk menyampaikan hasil pemikiran, perasaan dan pengalamannya tentang kesundaan dalam bentuk tulisan yang merefleksikan dirinya sebagai bagian dari urang Sunda yang punya tugas untuk ngamumule (melestarikan) budayanya. Dalam hal ini, Bahasa Sunda pun difungsikan tidak hanya sebagai alat komunikasi, juga sebagai alat pengembang dan pendukung kebudayaan Sunda itu sendiri (Pikiran Rakyat, 19/2/2005). Media cetak berbahasa Sunda yang sampai saat ini masih terbit di Kota Bandung antara lain Mangle, Galura, Sunda Midang dan Cupumanik. Selain itu, para penulis pun menyalurkan hasil pemikirannya tentang kesundaan dalam Bahasa Indonesia di surat kabar nasional. Tulisan yang dihasilkan 
merupakan hasil adaptasi terhadap kondisi diri penulis dan lingkungan. Pengalaman hidup yang dialaminya serta cara penulis memandang diri dan lingkungannya secara sadar maupun tidak sadar turut mempengaruhi tema cerita dan pemilihan jenis tulisan yang dihasilkannya. Lingkungan yang dimaksud dapat berupa realitas sosial, politik dan budaya di tempat penulis berada.

Pada Penulis Sunda, cara pandang dan perasaan dirinya sebagai bagian dari urang Sunda merupakan hasil pengalaman dan interaksi dengan orang lain serta ikatan emosional dengan kondisi lingkungan yang dihadapinya. Dalam konteks fenomenologis, Penulis Sunda merupakan pelaku tindakan sosial yang memaknai realitas sosial berdasarkan hasil interaksinya dengan diri sendiri, lingkungan dan individu lain dalam masyarakat sebagai narasumber tulisannya Interaksinya tersebut menghasilkan pemaknaan intersubyektif yang dituangkan ke dalam tulisan setelah melalui proses berpikir dan penghayatan dalam diri penulis. Menurut Alfred Schutz (1981: 123) dalam Kuswarno (2009: 110), makna intersubyektif berawal dari konsep "sosial" dan "tindakan". Konsep sosial didefinisikan sebagai hubungan antara dua atau lebih orang dan konsep "tindakan" didefinisikan sebagai perilaku yang membentuk makna subyektif. Oleh karenanya sebuah makna subyektif disebut sebagai makna intersubyektif.

Berdasarkan pemikiran Schutz, proses pembentukan makna terhadap realitas sosial didasari pada dua motif, yaitu motif untuk (in order to motive) dan motif sebab (because motive). 'Motif untuk' menunjuk pada tujuan dari tindakan dan 'motif sebab' merupakan pengalaman masa lalu yang mendasari tindakan yang dilakukan saat ini. Penulis Sunda memiliki salah satu dari dua motif yakni motif yang berorientasi pada masa depan atau motif yang berorientasi pada masa lalu. Tentu saja motif tersebut akan menentukan penilaian terhadap dirinya sebagai Penulis Sunda. Dalam pandangan fenomenologis, Penulis Sunda adalah subyek "pelaku kehidupan" yang memiliki hasrat, keinginan, harapan, dan kehidupan sendiri yang unik. Pengalaman masa lalu dan tujuan yang ingin dicapai dari tulisannya, merupakan dua sisi yang menarik untuk dikaji. Pengalaman tersebut mewujud pada pemilihan tema dan jenis karya tulis yang dipilih sebagai media penyampai pesan, yang menjadi ciri khas dari penulis berdasarkan persepsinya terhadap realitas. Rangkaian proses penyampaian pesan pun dilakukan Penulis Sunda untuk menghasilkan tulisannya.

Sebagai bagian dari urang Sunda, para informan merasakan adanya panggilan untuk melestarikan budaya yang 
membentuknya. Dengan demikian, penulis menempatkan diri sebagai pelestari Budaya Sunda. Dengan kemampuannya menulis, maka melalui tulisanlah para informan penelitian ini berperan sebagai pelestari Budaya Sunda.

\section{FOKUS DAN PERTANYAAN} PENELITIAN

Berdasarkan paparan dalam latar belakang maka fokus penelitian ini adalah: "Bagaimana Pengalaman Berkomunikasi Penulis Sunda sebagai Pelestari Budaya?”. Adapun Pertanyaan penelitian ini adalah:

1. Apa motif informan menjadi Penulis Sunda?

2. Bagaimana konstruksi makna diri Penulis Sunda sebagai pelestari budaya?

3. Bagaimana proses penyampaian pesan Penulis Sunda sebagai pelestari budaya?

\section{KERANGKA PEMIKIRAN}

Penulis adalah orang kreatif. Mereka mampu merekonstruksi realitas yang dialami maupun diamatinya ke dalam bentuk tulisan, sastra maupun ninsadanysetelah melakukan pemaknaan terhadap realitas tersebut melalui interaksi dengan dirinya sendiri dan lingkungan sosialnya. Adanya interaksi dengan diri dan lingkungan merupakan pengalaman tersendiri bagi penulis yang mempengaruhi dalam menuangkan idenya ke dalam tulisan.

Berdasarkan wawancara dengan beberapa informan, Penulis Sunda adalah seseorang yang menuangkan pemikiran dan perasaannya mengenai kesundaan dalam bentuk karya tulis sastra maupun nonsastra dalam Bahasa Sunda atau Bahasa Indonesia. Media yang umum digunakan untuk menyampaikan hasil karyanya tersebut adalah surat kabar, majalah dan buku serta media online (blog dan website).

Berbagai pengalaman yang dialami Penulis Sunda dalam menghasilkan tulisannya merupakan hal yang menarik untuk diungkapkan, apalagi para penulis yang dijadikan informan penelitian masih konsisten menulis dalam Bahasa Sunda meskipun peminat karya tulis Sunda relatif tidak bertambah. Jika diasumsikan konsistensi penulis untuk menulis tentang kesundaan merupakan suatu fenomena, maka untuk dapat menelitinya, digunakan teori dan konsep-konsep sebagai panduan dalam mengungkap fenomena tersebut. Teori tersebut adalah teori fenomenologi dan konsep-konsep yang digunakan adalah Budaya Sunda, bahasa, konstruksi makna dan pelestarian budaya. Melalui teori dan konsep-konsep tersebut, peneliti berupaya memaparkan pengalaman berkomunikasi Penulis Sunda sebagai pelestari budaya 
melalui tulisan yang diungkapkan dari sudut pandang penulisnya langsung.

\section{Teori Fenomenologi}

Fenomenologi termasuk ke dalam kelompok teori subyektif. Menurut teori ini, realitas dikonstruksi menurut sudut pandang subyek yang dijadikan partisipan penelitian. Peneliti sebagai instrumen penelitian, mencoba merangkai pengalaman subyek yang diteliti menjadi realitas yang ditemukan sesuai sudut pandang mereka. Kuswarno (2009: 2) mengungkapkan, fenomenologi mencoba mencari pemahaman bagaimana manusia mengonstruksi makna dan konsep-konsep penting dalam kerangka intersubyektifitas. Disebut intersubyektif karena pemahaman kita mengenai dunia dibentuk oleh hubungan kita dengan orang lain.

Fenomenologis tidak berasumsi bahwa peneliti mengetahui mengenai orang yang ditelitinya. Konstruksi kebenaran yang dibangun oleh peneliti, harus memegang teguh prinsip bahwa peneliti hanya menemukan permasalahan, bukan membuktikannya. Kunci penemuan kebenaran ada pada subyek yang ditelaah atau orang yang ditemukan masalahnya.(Bajari, 2009: 75).

Littlejohn (1996: 204), menyebutkan "phenomenology makes actual lived experience the basic data of reality". Jadi, fenomenologi menjadikan pengalaman hidup sesungguhnya sebagai data dasar dari realitas.

Mengutip pendapat Richard E. Palmer, Littlejohn menjelaskan bahwa fenomenologi berarti membiarkan segala sesuatu menjadi nyata sebagaimana aslinya tanpa memaksakan kategori-kategori peneliti terhadapnya.

Teori fenomenologi yang digunakan dalam penelitian ini adalah yang dikembangkan oleh Edmund Husserl dan Alfred Schutz. Edmund Husserl adalah seorang ahli matematika Jerman, yang dikenal sebagai Bapak Fenomenologi. Husserl meletakkan dasar-dasar fenomenologi sebagai aliran filsafat dengan menyatakan bahwa kebenaran fenomena seperti tampak apa adanya. Husserl mengkhususkan pembahasannya pada fenomenologi sebagai ilmu mengenai pokok-pokok kesadaran (the science of the essence of conciousness). Husserl (1913), dalam Kuswarno, (2009: 10) berpendapat, dengan fenomenologi dapat dipelajari bentuk-bentuk pengalaman dari sudut pandang orang yang mengalaminya secara langsung, seolah-olah kita mengalaminya sendiri. Realita dalam fenomenologi adalah cara bagaimana berbagai hal muncul dalam persepsi sadar dari individu.

Sementara Alfred Schutz adalah seorang filsuf fenomenologi yang dilahirkan 
di Viena, Austria. Alfred Schutz adalah orang pertama yang menerapkan fenomenologi yang digagas Edmund Husserl ke dalam penelitian ilmu sosial. Schutz meletakkan hakikat manusia dalam pengalaman subyektif, terutama ketika mengambil tindakan dan mengambil sikap terhadap dunia kehidupan sehari-hari. Teori fenomonologi yang diperdalam Schutz merupakan penyempurnaan atas konsep transendental Husserl yang digabungkan dengan konsep verstehen Max Weber (Waters, 1994: 34-35), yang mengarah pada suatu tindakan bermotif pada tujuan yang hendak dicapai. Schutz menyebut manusia yang berperilaku tersebut sebagai aktor. Ketika seseorang melihat atau mendengar yang dikatakan atau diperbuat aktor, dia akan memahami makna dari tindakan tersebut. Dalam dunia sosial hal demikian disebut realitas interpretif atau interpretive reality.

Menurut Mulyana (2004: 63), bagi Schutz, tugas utama analisis fenomenologis adalah merekonstruksi dunia kehidupan manusia "sebenarnya" dalam bentuk yang mereka alami. Realitas dunia tersebut bersifat intersubyektif dalam arti anggota masyarakat berbagi persepsi dasar mengenai dunia yang mereka internalisasikan melalui sosialisasi dan memungkinkan mereka melakukan interaksi dan komunikasi. Schutz membagi tindakan seseorang ke dalam dua motif, yaitu tindakan in-order-to-motive yang merujuk pada masa datang; dan tindakan because motive yang merujuk pada masa lalu.

\section{KERANGKA KONSEPTUAL}

Pada bagian ini, dipaparkan beberapa konsep yang digunakan sebagai acuan dalam penelitian ini, yaitu komunikasi, Budaya Sunda,bahasa dan konstruksi makna. Konsep-konsep tersebut dijabarkan pada penjelasan sebagai berikut:

\section{Komunikasi}

Effendy (1993: 28) menyatakan, hakikat komunikasi adalah proses penyampaian pikiran atau perasaan seseorang kepada orang lain menggunakan bahasa sebagai alat penyalurnya. Pikiran atau perasaan yang disampaikan dinamakan pesan. Effendy (2007: 11-19) membagi proses penyampaian pesan tersebut ke dalam dua tahap, yaitu proses komunikasi primer dan proses komunikasi sekunder. Proses komunikasi primer merupakan proses penyampaian pikiran dan atau perasaan seseorang kepada orang lain menggunakan lambang (simbol) sebagai media, antara lain, bahasa, isyarat, gambar dan warna. Bahasa paling banyak digunakan dalam komunikasi, karena hanya bahasa yang mampu "menerjemahkan" pikiran dan perasaan seseorang kepada orang lain. 
Bentuknya bisa ide, informasi atau opini, mengenai hal kongkret maupun abstrak, tentang hal atau peristiwa yang terjadi saat sekarang, masa lalu dan masa datang. Sedangkan proses komunikasi sekunder adalah tahap lanjutan dari komunikasi proses komunikasi primer, yaitu proses penggunaan alat atau sarana sebagai media kedua setelah memakai lambang sebagai media pertama. Media digunakan, karena penerima pesan berada di tempat yang relatif jauh atau jumlahnya banyak.

Dalam konteks penelitian ini, proses penyampaian pesan dari penulis disampaikan dalam dua tahap sekaligus, yaitu bahasa sebagai media pertama, yang diwujudkan dalam bentuk tulisan dan penggunaan media sebagai alat kedua penyampaian pesan dari penulis. Dengan penggunaan media sebagai alat penyampai pesan, maka komunikasi yang dilakukan oleh penulis disebut komunikasi bermedia (mediated communication). Menurut Effendy (2007: 17).

Media yang digunakan penulis cukup beragam. Tapi, sebagian besar penulis masih mengandalkan media cetak, seperti surat kabar, tabloid, majalah dan buku untuk menyampaikan pesan kepada pembacanya. Melalui media inilah, penulis menyampaikan pikiran dan perasaannya menggunakan bahasa secara tertulis. Pada perkembangannya, penyampaian pesan dari penulis, tidak hanya melalui media cetak, juga melalui media online, seperti website, blog dan facebook, serta melalui saluran lain, misalnya film, radio, dan pertunjukkan seni.

\section{Budaya Sunda}

Budaya merupakan kompleks kebiasaan yang biasa dilakukan dalam kehidupan sehari-hari sebagai ungkapan untuk memahami dan menempatkan diri dalam kehidupan (Garna, 2008: ix). Budaya berasal dari kata buddhayah, yang berarti budi dan akal. Kebudayaan merupakan perkembangan dari kata budidaya, yaitu daya dari budi atau kekuatan dari akal (Garna, 2008: 147).

$$
\text { Melalui akalnya, manusia }
$$
memberdayakan dirinya untuk bertahan hidup. Dari proses pemberdayaan tersebut, manusia menghasilkan budaya yang mewujud dalam tiga bentuk yaitu wujud ideal berupa pola kompleks dan gagasan, nilai-nilai, norma, aturan dan etika; wujud sistem berupa kompleks aktivitas kelakuan berpola dari anggota masyarakat; serta wujud fisikal berupa benda-benda fisik karya manusia (Garna, 2008: 148). Setiap orang dilahirkan dalam pola budaya tertentu, yang memiliki tradisi dan diwarisinya melalui waktu yang panjang dari generasi ke generasi berikutnya. Mengacu pada definisi budaya yang diungkapkan Garna, maka pola kebiasaan yang dilakukan oleh Suku Sunda 
dalam memahami dan menempatkan diri dalam kehidupan disebut Budaya Sunda.

Dalam perkembangannya, budaya akan menyesuaikan diri dengan perkembangan zaman sehingga memunculkan kebiasaan-kebiasaan baru sebagai bentuk adaptasi terhadap perkembangan zaman. Munculnya kebiasaan-kebiasaan baru tersebut, dikhawatirkan merusak nilai-nilai budaya yang menjadi jatidiri orang Sunda. Untuk itu, para pelaku Budaya Sunda merasa perlu untuk melakukan pelestarian budaya sebagai satu-satunya cara untuk mengembalikan nilai-nilai budaya Sunda ke masa kejayaannya (Garna, 2008: ix).

Bagi para Penulis Sunda, salah satu cara yang bisa dilakukan untuk melestarikan budaya daerahnya adalah melalui tulisan. Melalui tulisan, para Penulis Sunda menyampaikan pesan dengan memanfaatkan bahasa sebagai alat komunikasi. Menurut Budhisantoso (1990: 4), bahasa sangat besar peranannya dalam menjalin komunikasi. Bahasa merupakan alat komunikasi antarmanusia sekaligus milik manusia yang sangat berharga. Dengan bahasa, manusia dapat dapat mengawetkan dan melestarikan kebudayaan dari satu generasi ke generasi selanjutnya.

\section{Bahasa}

Cassandra L. Book (dalam Mulyana 2007: 267) mengemukakan, agar komunikasi berhasil, setidaknya bahasa harus memenuhi tiga fungsi, yaitu untuk mengenal dunia sekitar kita, berhubungan dengan orang lain dan menciptakan koherensi atau keselarasan dalam kehidupan kita. Menurut Hamid Hasan Lubis (1993), fungsi-fungsi bahasa tidak dapat dilepaskan dari situasi tempat fungsi itu dijalankan. Ketika tujuan komunikasi sudah ditetapkan, untuk mencapainya, maka cara melaksanakan kegiatan berbahasanya disesuaikan dengan kondisi dan situasi tempat fungsi bahasa akan dilaksanakan.

Adanya bahasa memungkinkan manusia berkomunikasi atau mempertukarkan informasi. Menurut Berelson dan Steiner (1964: 527, dalam Wiryanto, 2004: 7) komunikasi adalah penyampaian informasi, ide, perasaan, keterampilan dan lain-lain melalui penggunaan simbol-simbol, kata-kata, gambar, angka dan sebagainya. Simbol atau pesan erat kaitannya dengan penggunaan bahasa sebagai media untuk mentransfer pikiran antarmanusia. Sarah Trenholm dan Arthur Jensen (1996: 4) dalam Wiryanto (2004: 6) mengartikan komunikasi sebagai proses mentransmisikan pesan dari sumber kepada penerima melalui beragam saluran. 
Penggunaan bahasa sebagai media penyampai informasi mewujud dalam berbagai bentuk. Salah satunya tulisan, yang merupakan hasil penciptaan atau kreasi dari seorang penulis, yang dapat diinformasikan dan disosialisasikan kepada orang lain. Melalui bahasa, para Penulis Sunda mengonstruksi realitas sebagai suatu pesan yang dikomunikasikan kepada pembacanya. Merujuk apa yang disampaikan oleh Hamid Hasan Lubis, maka dalam menyampaikan tulisannya pun, para penulis mempertimbangkan konteks situasi dan kondisi yang dihadapinya, sehingga tulisannya bisa dikemas sedemikian rupa, supaya enak dibaca, memiliki konteks kekinian dan bisa dipahami oleh pembaca dengan mudah, sehingga apa yang ingin disampaikannya dapat dipahami dengan baik.

\section{Konstruksi Makna}

Segala aspek dalam kehidupan individu bisa diberi makna, mulai dari benda yang kasat mata, sampai yang tidak terlihat berupa gagasan atau perasaan. Makna terbentuk melalui proses berpikir individu terhadap aspek yang ingin diberi makna, berlandaskan pada muatan informasi yang dimilikinya. Proses berpikir individu dipengaruhi faktor-faktor dalam dirinya, seperti sistem nilai, kepercayaan dan sikap sehingga makna yang dihasilkan individu terhadap suatu obyek yang sama akan berbeda. Seperti dijelaskan oleh Kaye (1994: 39) bahwa "Communication is about thinking. More precisely, it is concerned with the construction of meaning". Dalam memahami makna, Joseph DeVito (1998: 141) mengungkapkan: Look for meaning in people, not in words. Meaning change but words are relatively static, and share meanings, not only words, through communication. Makna terhadap sesuatu dapat terus berubah seiring perubahan waktu dan perkembangan lingkungan yang akan mengubah sistem nilai, kepercayaan dan sikap seseorang terhadap sesuatu.

Bahasa atau simbol adalah alat agar makna dimunculkan. Setiap individu memiliki cara tersendiri untuk mengekspresikan pikiran itu, melalui pilihan simbol yang digunakannya. Ogdens dan Richard dalam Mulyana (2007: 282). Makna muncul dari hubungan antara pikiran orang dengan simbol atau antara pikiran orang dengan referen. Sedangkan antara referen/obyek dengan simbol/kata tidak terdapat hubungan langsung atau alamiah di antara keduanya. Artinya bahwa tidak selalu suatu kata mewakili sebuah obyek. Seringkali karena perbedaan budaya, sistem nilai, kepercayaan mempengaruhi kata yang digunakan untuk merujuk suatu obyek. Dalam konteks Penulis Sunda, maka tulisan yang dihasilkan merupakan bentuk 
pemaknaan terhadap realitas yang diolah melalui proses berpikir yang diinterpretasikan sesuai dengan referensi, nilai dan kepercayaan yang dianutnya. Dengan demikian, setiap penulis memiliki interpretasi yang berbeda terhadap realitas yang terjadi.

\section{Pelestarian Budaya}

A.W. Widjaja (1986) dalam Ranjabar (2006: 115) mengartikan pelestarian sebagai kegiatan yang dilakukan terus menerus, terarah dan terpadu guna mewujudkan tujuan tertentu yang mencerminkan adanya sesuatu yang tetap dan abadi, dinamis, luwes, dan selektif. Mengenai pelestarian budaya lokal, Jacobus Ranjabar (2006: 114) mengemukakan bahwa pelestarian norma lama bangsa (budaya lokal) adalah mempertahankan nilai-nilai seni budaya dan nilai tradisional dengan mengembangkan perwujudan yang bersifat dinamis, luwes dan selektif, serta menyesuaikan dengan situasi dan kondisi yang selalu berubah dan berkembang.

Salah satu tujuan diadakannya pelestarian budaya adalah untuk melakukan revitalisasi atau penguatan budaya. Menurut Chaedar Alwasilah, revitalisasi kebudayaan dapat didefinisikan sebagai upaya yang terencana, berkelanjutan dan disengaja agar nilai-nilai budaya itu bukan hanya dipahami para pemiliknya, juga membangkitkan segala wujud kreativitas dalam kehidupan sehari-hari dalam menghadapi berbagai tantangan. Ada tiga langkah untuk penguatan budaya yaitu : (1) pemahaman untuk menimbulkan kesadaran, perencanaan secara kolektif, dan (2) pembangkitan kreatifitas kebudayaaan. (Alwasilah, 2006: 18)

Wujud budaya menjadi hal penting dalam pelestarian. Artinya budaya yang akan dilestarikan masih ada dan diketahui walaupun pada perkembangannya semakin terkikis atau dilupakan. Pelestarian hanya bisa dilakukan secara efektif ketika benda atau hal yang dilestarikan itu tetap digunakan dan tetap ada pengusungnya. Ketika budaya itu tidak lagi digunakan, maka budaya itu akan hilang. Upaya yang dilakukan Penulis Sunda, merupakan suatu bentuk penguatan atau revitalisasi budaya yang menahan Budaya Sunda dari kepunahan akibat perkembangan zaman. Lewat tulisan pula, para penulis dapat melestarikan berbagai wujud lainnya dari budaya, misalnya tentang nilai-nilai hidup orang Sunda, karakter orang Sunda dan sejarah tentang kesundaan.

Dengan demikian, tulisan yang dapat dikategorikan melestarikan Budaya Sunda, adalah tulisan yang menggambarkan orang Sunda dan kesundaan, baik secara karakter maupun nilai-nilai hidup yang dianutnya, serta perilaku dalam kehidupan sosial serta 
sejarah. Misalnya falsafah hidup, agama, humor, hubungan sosial, budaya dan kesejarahan.

Berdasarkan penjelasan tentang landasan teoritis tersebut, maka fenomena METODOLOGI

\section{- Subyek Penelitian}

Subyek penelitian ini adalah Penulis Sunda, yaitu individu yang berkarya menuangkan pikirannya melalui karya tulis tentang kesundaan yang disebarluaskan melalui media massa cetak (surat kabar, majalah) dan buku, untuk diketahui dan dipahami pembacanya. Untuk memperoleh hasil penelitian yang relevan, maka subyek penelitian atau informan yang dijadikan narasumber dipilih berdasarkan kriteria tertentu yang sesuai denga acuan dalam menentukan subyek penelitian, yaitu secara umum dikenal sebagai Penulis Sunda, yang menulis dalam bahasa Sunda maupun menulis tentang kesundaan dalam bahasa Indonesia.; Karya tulisan mereka banyak dipublikasikan; hasil karya tulisnya masih tetap ada dan banyak melahirkan ide-ide baru dalam menghasilkan karya.

Dalam penelitian ini, awalnya jumlah penulis Sunda mencapai 14 orang. Tapi berdasarkan proses reduksi, dengan berbagai pertimbangan, akhirnya terpilih delapan orang yang dijadikan informan dalam penelitian ini, yaitu Usep Romli, Us Tiarsa, Aam Amilia, Aan Merdeka Permana,
Penulis Sunda dapat digambarkan dalam kerangka pemikiran, sebagai berikut:

Eddy D. Iskandar, Taufik Faturohman, Hawe Setiawan dan Dadan Sutisna.

Peneliti memfokuskan lokasi penelitian di Kota Bandung, tempat para penulis biasanya berada. Lokasi pertemuan yang mudah diakses adalah tempat para penulis biasa beraktivitas atau sering berkunjung ke lokasi tersebut, yaitu kantor redaksi Majalah Mangle, Jalan Lodaya No. 19 Bandung, dan kantor redaksi Galura, Jalan Belakang Factory no. 2 A, Banceuy Bandung.

\section{- Obyek Penelitian}

Dalam penelitian ini, yang dijadikan obyeknya adalah pengalaman berkomunikasi Penulis Sunda sebagai pelestari budaya, yaitu menginformasikan dan melestarikan Budaya Sunda melalui tulisan. Gambaran tentang kegiatan menulis diperoleh dari penyataan-pernyataan yang disampaikan penulis ketika diwawancara. Hal ini dikarenakan pengamatan yang dilakukan bersifat nonpartisipan. Artinya peneliti tidak ikut serta langsung mengamati kegiatan penulis dalam menghasilkan tulisan, karena penulis memiliki waktu yang berbeda-beda untuk menghasilkan tulisan. 
Aspek-aspek yang menjadi obyek penelitian ini adalah pernyataan-pernyataan yang dikemukakan dan mengandung pandangan, sikap, pengetahuan dan pengalaman tentang bagaimana melahirkan suatu karya tulis sebagai bagian dari upaya pelestarian Budaya Sunda.

\section{- Metode Penelitian Kualitatif}

Fenomena penulis berhubungan erat dengan pengalaman individu sebagai mahluk sosial. Pengalaman individu memiliki banyak aspek yang tidak terlihat dan tidak dapat diubah. Untuk mengetahui hal-hal tersebut, digunakan metode penelitian kualitatif, yang berusaha menjelaskan cara pandang penulis sebagai subyek penelitian yang melihat kondisi dan konteks yang ada di sekitarnya, sebagai realitas yang bisa dimaknai. Penelitian kualitatif merupakan paradigma penelitian yang menekankan adanya pemahaman mengenai masalah-masalah dalam kehidupan manusia, berdasarkan kondisi realitas atau kondisi alamiah yang menyeluruh, kompleks dan rinci.

Bogdan dan Taylor (1975: 5) dalam Moleong (2006: 4) mengemukakan bahwa metodologi kualitatif merupakan prosedur penelitian yang menghasilkan data deskriptif berupa kata-kata tertulis maupun lisan dari orang-orang dan perilaku yang diamati. Dalam penelitian ini tidak dicari hukum umum atas suatu kebenaran atau generalisasi. Penelitian ini berusaha membangun pemahaman terhadap realitas fenomena sosial yang ada.

Dalam penelitian kualitatif, peneliti adalah instrumen kunci. Teori digunakan bukan sebagai unsur utama, melainkan sebagai pendukung penelitian. Hal ini dikarenakan, peneliti kualitatif justru harus membebaskan diri dari tawanan suatu teori agar fokus penelitian dapat berkembang sesuai kenyataan di lapangan (Faisal, 1990: 38), dalam Kuswarno (2009: 126).

Moleong (2006: 6) menyimpulkan, penelitian kualitatif adalah penelitian yang bermaksud memahami fenomena tentang apa yang dialami oleh subyek penelitian, misalnya perilaku, persepsi, motivasi, tindakan, secara holistik dengan cara deskripsi dalam bentuk kata-kata dan bahasa, pada suatu konteks khusus yang alamiah dengan memanfaatkan berbagai metode ilmiah. Masih menurut Moleong (2006: 14), penelitian kualitatif dengan pendekatan fenomenologi, merupakan suatu studi tentang kesadaran dari perspektif pokok seseorang melalui pengungkapan pengalaman subyektif atau pengalaman fenomenologikal yang berhubungan dengan suatu obyek.

Berdasarkan pemaparan tersebut, maka tujuan utama penelitian ini adalah berusaha menjelaskan pengalaman yang 
dimaknai Penulis Sunda dalam melestarikan budaya Sunda dari perspektif mereka. Konstruksi pengalaman diperoleh melalui hasil pengumpulan data wawancara mendalam dengan partisipan penelitian dan menempatkan diri peneliti sebagai instrumen utama.

\section{Teknik Pengumpulan Data}

Data dalam penelitian ini berupa data primer yang diperoleh langsung dari informan melalui wawancara mendalam, serta data sekunder berupa dokumen dan

\section{HASIL PENELITIAN}

\section{Motif menjadi Penulis Sunda}

Untuk memahami makna dari keberadaan Penulis Sunda sebagai Pelestari Budaya Sunda, maka perlu diketahui motifnya. Alfred Schutz membagi motif menjadi motif 'untuk' (in order to motive) dan motif 'sebab' (because motive). Motif 'untuk' merupakan tujuan yang digambarkan sebagai maksud, rencana, harapan, minat dan sebagainya yang berorientasi masa depan. Sedangkan motif 'sebab', merujuk pada pengalaman masa lalu individu tersebut. Schutz menjelaskan bahwa motif adalah konteks makna yang tampak pada individu sebagai landasan makna perilakunya.

Dalam penelitian ini, motif 'sebab' diasumsikan sebagai 'aspek pendorong' dan publikasi hasil karya Penulis Sunda atau tentang Penulis Sunda yang diperoleh dengan cara observasi nonpartisipan dan kajian literatur.

Dalam melakukan wawancara dengan informan, digunakan alat bantu berupa pedoman wawancara, tape recorder, kamera untuk mendokumentasikan proses wawancara. Selain itu juga peneliti juga menggunakan teknik dokumentasi, yaitu penulusuran dan pemerolehan data yang diperlukan melalui browsing internet, arsip, foto, maupun bentuk dokumentasi lainnya.

motif 'untuk' sebagai 'aspek harapan'. 'Aspek pendorong' merupakan kondisi-kondisi masa lalu yang membentuk pribadi informan yang memunculkan kesadaran untuk menjadi Penulis Sunda. Sementara 'aspek harapan', merupakan keinginan-keinginan dari para informan terkait dengan keberadaannya sebagai Penulis Sunda.

Secara garis besar, yang menjadi pendorong para informan untuk menjadi Penulis Sunda didasari oleh kebiasannya membaca, yang dipengaruhi oleh lingkungan, baik lingkungan keluarga maupun lingkungan selain keluarga. Hasil bacaannya itu kemudian mengendap dan memunculkan keinginan dari para informan untuk mengeskpresikan perasaan dan 
pemikirannya tentang hal-hal yang dilihat dan dipahaminya ke dalam tulisan.

Meski membaca menjadi alasan utama yang dikemukakan oleh para informan untuk menjadi Penulis Sunda, tetapi ada beberapa kondisi spesifik yang menjadi aspek pendorong bagi para informan untuk menjadi Penulis Sunda, yang terbagi ke dalam aspek ekstrinsik dan aspek intrinsik.

Kondisi-kondisi

lingkungan

keluarga bagi Us Tiarsa, Usep Romli dan Aam Amilia, kemudian pergaulan dengan

Penulis/Pengarang Sunda bagi Eddy D. Iskandar dan Hawe Setiawan, menonton Sandiwara Sunda bagi Aan Merdeka Permana, mendengarkan Dongeng Sunda bagi Dadan Sutisna dan menang lomba mengarang bagi Taufik Faturohman, menjadi pendorong ekstrinsik mereka untuk menjadi Penulis Sunda.

"Lingkungan keluarga saya sangat senang membaca. Setiap malam, nenek saya, kakek saya membaca buku-buku Sunda, dari wawacan, roman atau novel. Saya pun lebih banyak bergaul dengan bahasa Sunda, mulai menulis dalam bahasa Sunda dan saya juga bekerja di media Bahasa Sunda sejak awal. Orang Sunda punya media bahasa Sunda dan itu saya gunakan sebaikbaiknya. Saya kira itu, mengapa saya masih menggeluti bahasa Sunda. ' (Us Tiarsa)

"Di rumah banyak buku dan saya suka membaca. Mungkin terbentuk dari kesukaan membaca. Bapak ingin mengekspresikan dalam bentuk tulisan. Kebetulan Bapak hidup di lingkungan orang Sunda,

${ }^{1}$ Wawancara Us Tiarsa, 14 Februari 2011 menguasai Bahasa Sunda. Jadi Bapak menulis dalam Bahasa Sunda. Mengekspresikan dalam Bahasa Sunda". ${ }^{2}$ (Usep Romli)

"Da baheula mah reueus atuh jadi urang Sunda teh. Bacaan teh kabeh ku Basa Sunda. Sastra-sastra dunia teh dina Basa Sunda baheula mah. Ralph de Montekristo, Ibu macana dina Bahasa Sunda. Bangsa Robinson Crusoe, eta teh ku Basa Sunda baheula mah. Nuju tujuhbelas taun, kelas dua SMA. Eta Sunda. Nulisna teh kelas dua SMA, tapi dimuatna geus Ibu kawin, geus kuliah..Kapendakna ku Pa Rustandi. Mun teu kapendak ku Pa Rustandi mah, boa teuing muncul, boa teuing henteu. Dimunculkeun, dipuji, terus maju". ${ }^{3}$ (Aam Amilia)

"Sejak di bangku SMA saya sudah mencoba menulis Bahasa Sunda. Tapi lebih percaya diri setelah di perguruan tinggi dan banyak bergaul dengan pengarang- pengarang, seperti Pa Usep, Pak Abdullah, Ibu Aam, Pak Juniarso Ridwan dan Godi Suwarna. Saya menulis dalam Bahasa Sunda, karena Bahasa Sunda lebih kaya ketika diekspresikan dalam bentuk karya tulis". 4 (Eddy D. Iskandar)

"Tahun 2000. Saya jadi penyunting di penerbit Pustaka Jaya. Sebelum masuk Pustaka Jaya, saya dan Ajip Rosidi biasa berkorespondensi, sejak kenal melalui tugas jurnalistik saya. Dia selalu ngirim surat dari Osaka itu dalam Bahasa Sunda. Saya sulit sekali menjawab. Saya selalu menjawab pake Bahasa Indonesia. Bahkan ketemu Ajip pertama kali, bicara dalam Bahasa Indonesia. Jadi saya jelaskan ke Ajip, saya kayak dibunuh dua kali. Menjadi Sunda tidak, menjadi Indonesia juga nggak. Ajip selalu ngirimin surat pake Bahasa Sunda, saya lama-lama dendam juga.

\footnotetext{
${ }^{2}$ Wawancara Usep Romli, 1 Oktober 2010

${ }^{3}$ Wawancara Aam Amilia, 28 Maret 2011

${ }^{4}$ Wawancara Eddy D. Iskandar, 6 Juni 2011
} 
Gimana caranya... Jadi diam-diam, selama jadi penyunting di Pustaka Jaya, saya menyempatkan diri pergi ke Perpustakaan Nasional. Membuka-buka buku pengajaran Bahasa Sunda untuk sekolah dasar, terbitan tahun 20-an karangan Raden Suryadireja. Terutama buku-buku untuk pr-nya. Saya fotokopi diam-diam. Esei-eseinya, tugas mengarang, saya kerjakan. Terus kamusnya saya baca, tata bahasanya saya baca, kirakira beberapa minggu gitu. Nah, setelah merasa menguasai, saya coba praktek nulis. Surat dulu. Ngejawab ke Ajip pake Bahasa Sunda. Poin saya adalah, saya bisa menulis dalam Bahasa Sunda dan seperti kembali ke rumah masa kecil. Jadi, ada segi nostalgic. Seperti kembali ke rumah Ibu. Saya seneng sekali bisa nulis dalam Bahasa Sunda dan cukup produktif tahun 2002 itu. sampai kemudian banyak temen pengarang Bahasa Sunda." (Hawe Setiawan)

"Dari SD, kan sering nonton sandiwara Sunda. Jadi awalnya sok sasandiwaraan sama teman-teman tetangga teh, biasa jadi raja dan ksatria. Terus ceritanya tidak mau yang sudah ada "geus weh nyieun sorangan,". Nah, jadi, bikin cerita kan, buat teman-teman. Terus di SMP, suka bikin cerita. Ditulis tangan di buku tulis. Dibaca sama teman-teman sekelas. Teman-teman sering bertanya "Mana An, ngarang deui," " tah ieu aya.." terus dibaca. Terus ada yang menyarankan buat dikirim ke Mangle, siapa tau dimuat. Ternyata bener...dimuat. Jadi ada semangat pendorong untuk melanjutkan. Kesananya sugan teh babari jadi pengarang teh..ah teu dimaruat (ketawa). Ngan Pa Aan geus kagok era, diakukeun pengarang. Terus aja bikin, sugan weh dimuat..." 6 (Aan Merdeka Permana)

"Waktu SD-SMP, saya suka mendengarkan dongeng Sunda di radio. Yang saya tulis itu kira-kira seperti itu. Awalnya, obsesi saya menulis dongeng Sunda, mungkin suatu saat

\footnotetext{
${ }^{5}$ Wawancara Hawe, 28 September 2010

${ }^{6}$ Wawancara Aan, 1 November 2010
}

dibacakan oleh pendongeng dan ikut didengarkan oleh masyarakat. Waktu SMA kebetulan ada teman yang berlangganan Majalah Mangle. Kemudian saya pinjem, teras maca. Oh, ternyata ada bentuk lain dalam menulis itu, misalnya cerpen..."7 (Dadan Sutisna)

"Sebenarnya tidak sengaja. Waktu saya kelas dua SMA, kan suka ada pelajaran mengarang. Nah mungkin Pak Aon Abdulmuin, guru saya di SMA 2 Tasikmalaya melihat, yang namanya Taufik Faturohman ini ada bakat menulis. Waktu ada lomba mengarang antar siswa SMA sekabupaten Tasikmalaya, saya disuruh ikut lomba, enggak sengaja padahal. Saya ikut, saya juara sekabupaten. Dapat beasiswa dapat hadiah. Nah, saya tau, mungkin saya ada bakat menulis. "8 (Taufik Faturohman)

Aspek pendorong intrinsik informan menjadi Penulis Sunda terdiri dari, panggilan jiwa bagi Us Tiarsa, bakat bagi Usep Romli dan Taufik Faturohman, terbatasnya keterampilan sebagai seorang perempuan pada Aam Amilia, mengenalkan sejarah Sunda pada Aan Merdeka Permana, ingin mengenalkan Sunda lebih luas bagi Eddy D. Iskandar dan Hawe Setiawan, serta ingin meniru pendongeng bagi Dadan Sutisna.

"Itu secara tegas saya katakan. Saya punya misi, ingin membangun dan menjaga kebudayaan. Karena saya orang Sunda dan mulai menulis dalam Bahasa Sunda dan saya bekerja juga di media Bahasa Sunda sejak awal. Di organisasi juga organisasi Sunda. Jadi lebih banyak bergaul dengan Bahasa Sunda". ${ }^{9}$ (Us Tiarsa)

\footnotetext{
${ }^{7}$ Wawancara Dadan, 11 Oktober 2010

${ }^{8}$ Wawancara Taufik, 5 Oktober 2010

${ }^{9}$ Wawancara Us Tiarsa, 6 Juli 2011
} 
"Kalau Bapak mah, secara awal mungkin sudah punya bakat menulis. Dengan rangsangan-rangsangan berbagai hal, sekarang mah bakat ku butuh, sebagai mata pencaharian. Syukur ka Alloh udah ngasih bakat dan peluang untuk mengembangkan bakat. Saat jadi PNS ga ada waktu pisan untuk menulis. Karena lebih dulu sudah jadi penulis, walaupun Bapak PNS, Bapak berhenti jadi PNS dan jadi penulis. Daripada Bapak membunuh bakat lebih baik Bapak mengundurkan diri"10. (Usep Romli)

"Sebenarnya ada bakat juga, karena kakek saya, salah seorang redaksi majalah Al Intisal. Majalah yang terbit di Tasik tahun 1935, dikaluarkeun $k u$ guru ngaji Tasikmalaya. Jadi, kakek saya yang nulis artikel, nulis wawacan, karangan dalam bentuk pupuh. Waktu SMA saya ikutan lomba mengarang. Saya juara sekabupaten, dapat beasiswa dapat hadiah. Nah, saya tau, mungkin saya ada bakat menulis"."1 (Taufik Faturohman)

"Ari kabisa euweuh deui ngan nulis. Mun bisa ngabordel mah ngabordel atawa nyieun kueh. Nyieun kueh, da tutung wae atuh. Ngabordel kalah saroek...Jadi profesi Ibu ayeuna penulis". ${ }^{12}$ ("Ibu cuma bisa nulis. Habis...ngejahit atau bikin kue gak bisa. Bikin kue, selalu gosong...ngejahit malah pada sobek. Jadi...profesi ibu sekarang penulis”) (Aam Amilia)

"Mungkin mula-mula dipengaruhi kegemaran saya nonton sandiwara yang menceritakan cerita Pajajaran, atau cerita klasik. Nah, kadieunakeun, saya kehilangan jejak mengenai masa lalu Sunda. Ti SD keneh sampai SMA, kalau berbicara sejarah Sunda, kurang lebihnya, dahulu kala di Jawa Barat ada kerajaan Hindu bernama Pajajaran, rajanya Prabu Siliwangi. Tos weh ngan sakitu. Jadi, pengetahuan Sunda

\footnotetext{
${ }^{10}$ Wawancara Us Tiarsa, 6 Juli 2011

${ }^{11}$ Wawancara Taufik Faturohaman, 5 Oktober 2010

12 Wawancara Aam Amilia, 20 Oktober 2010
}

teh ngan sakitu. Tah, tidinya, saya ingin mengenal masa lalu negeri saya sendiri. Itu pun sesudah saya baca buku. Waktu lagi musim, film atau buku silat Cina, saya baca silat Cina. Sampai saya hafal sejarah perkembangan Cina jaman klasik. Terus, musik cerita-cerita Jepang, sampai saya hapal sejarah Jepang. Kebudayaan India. Nah, setelah semua dikunyah, ditelan, tibatiba saya jadi inget "Ari Sunda boga sejarah teu?".Jadi mungkin dari sana titik tolaknya." 13 (Aan Merdeka Permana)

"Saya menulis dalam Bahasa Sunda, karena Bahasa Sunda lebih kaya ketika diekspresikan dalam bentuk karya tulis. Kepuasaan batinnya terletak pada adanya tanggung jawab untuk memelihara bahasa, kultur, kesinambungan emosi kita dengan Kesundaan. Kepuasannya bukan materi, tapi kepuasan batin darimana saya berasal. Kita ingin melakukan sesuatu dengan karyakarya berbahasa Sunda dengan tematemanya juga, walaupun tidak seproduktif dengan menggunakan Bahasa Indonesia, tetapi ada buku yang diterbitkan, seperti puisi, kumpulan cerpen, novel. Ketika saya dipercaya menulis tentang Kesundaan, minimal berpikir bagaimana membuat Sunda itu ke arah nasional". ${ }^{14}$ (Eddy D. Iskandar)

"Menulis tentang tema-tema kesundaan dengan bahasa apapun, termasuk dengan Bahasa Inggris, harapan dan idealismenya sedapat mungkin membawa nilai Sunda ini ke jalan raya peradaban. Ya..siapa tau ada yang lewat. Ini apaan sih? oh..Sunda. Biar ikut memastikan kontribusi kebudayaan Sunda untuk peradaban global. Sunda teh sanes wae katinggal. Nanging oge maparin sumbangan kanu peradaban. Kan itu bagus. Kita adalah warga kampung kecil yang tidak bisa menutup diri. Jalan setapak. Nah, menulis itu adalah langkah kecil untuk

\footnotetext{
${ }^{13}$ Wawancara Aan Merdeka Permana, 1 November 2010

${ }^{14}$ Ibid
} 
membangun jalan setapak itu. Buat saya mah gitu sih." ${ }^{15}$ (Hawe Setiawan)

"Awalnya, obsesi saya menulis dongeng Sunda yang mungkin suatu saat dibacakan oleh pendongeng dan ikut didengarkan oleh masyarakat. Awalnya, enak aja nulis Bahasa Sunda. Salah satu yang membuat kenapa menulis dalam bahasa sunda itu, bagi saya mempunyai kepuasan tersendiri, mungkin dari sisi kata-kata, banyak yang saya kira, kalau dalam istilah bahasa Sunda itu merenah, dan tidak didapatkan dalam bahasa lainnya." ${ }^{6}$ (Dadan Sutisna)

Sementara itu, berdasarkan aspek harapan, yang merupakan keinginankeinginan dari para informan pada masa depan terkait dengan keberadaannya sebagai Penulis Sunda secara garis besar berkaitan dengan idealisme untuk melestarikan Budaya Sunda. Sedangkan, harapan yang lebih spesifik dari informan dengan menjadi Penulis Sunda adalah Bahasa Sunda terpelihara keberadaannya bagi Us Tiarsa, Usep Romli, Aam Amilia, Taufik Faturohman dan Dadan Sutisna. Kemudian Budaya Sunda dikenal luas bagi Eddy D. Iskandar dan Hawe Setiawan, serta Sejarah Sunda diketahui dan diakui bagi Aan Merdeka Permana.

$$
\text { Harapan agar Bahasa Sunda }
$$
terpelihara keberadaannya dilakukan Us Tiarsa dengan selalu menulis dalam Bahasa Sunda yang baik dan benar dalam cerpen maupun tulisan lainnya. Kemudian Usep

\footnotetext{
${ }^{15}$ Wawancara Hawe Setiawan, 28 September 2010

${ }^{16}$ Wawancara Dadan Sutisna, 29 April 2011
}

Romli dan Dadan Sutisna berusaha untuk selalu produktif menghasilkan karya baru dari sisi kuantitas, maupun dari pengembangan tema. Mereka pun bersama para pengarang lainnya yang bernaung dalam Paguyuban Panglawungan Sastra Sunda (PPSS), secara rutin setiap tahun melakukan Saba Sastra, yaitu kunjungan ke sekolah-sekolah di daerah untuk mengenalkan Sastra Sunda kepada para siswa sekolah menengah.

Demikian pula halnya dengan Aam Amilia, yang sampai sekarang produktif menghasilkan karya tulis dalam Bahasa Sunda. Bahkan dengan prinsip bahwa tulisan itu harus memiliki unsur informasi, pendidikan dan hiburan, maka untuk menjaga kelangsungan prinsipnya itu, Aam selalu mengamati tulisan para Penulis Sunda generasi sekarang untuk melihat perkembangan penggunaan Bahasa Sunda dalam tulisan. Selain itu, Aam juga pernah membagikan ilmunya kepada Penulis Sunda tentang bagaimana menulis dalam Bahasa Sunda yang baik dan benar. Salah satu muridnya adalah Taufik Faturohman, yang kini dikenal sebagai Penulis Humor Sunda. Dengan predikatnya tersebut, selain untuk menghibur, Taufik juga ingin masyarakat, mulai dari anak-anak sampai orang tua mencintai Bahasa Sunda, sehingga Bahasa Sunda dihargai. 
Kemudian, dengan harapan ingin membawa Budaya Sunda dikenal lebih luas, maka Eddy D. Iskandar selalu berupaya untuk membuat tulisan dalam Bahasa Sunda atau tentang Sunda dengan pola pikir nasional, seperti yang pernah dilakukannya dengan menulis naskah film si Kabayan dan beberapa serinya. Sementara Hawe, yang ingin membawa Budaya Sunda dikenal secara lebih global di dunia internasional, maka ia berupaya untuk menulis tentang kesundaan dalam Bahasa Inggris, yang ia tuangkan ke dalam blog miliknya, yaitu http: //Sundanesecorner.org.

Sementara itu, harapan agar sejarah Sunda diketahui dan diakui oleh masyarakat diwujudkan Aan Merdeka Permana dengan aktif menulis cerita dengan latar belakang Sejarah Sunda, yang sudah dirintisnya sejak tahun 1989, dengan menulis novel Senja Jatuh di Pajajaran yang mencapai tiga seri.

\section{KONSTRUKSI MAKNA PENULIS SUNDA SEBAGAI PELESTARI \\ BUDAYA}

Menurut Berger \& Luckmann (1990, 28-35) kehidupan sehari-hari menampilkan diri sebagai kenyataan yang ditafsirkan oleh manusia dan mempunyai makna subyektif bagi mereka sebagai satu dunia yang koheren. Kenyataan hidup sehari-hari itu selanjutnya menghadirkan diri kepada individu sebagai suatu dunia yang intersubyektif, suatu dunia yang dihuni bersama-sama dengan orang lain. Husserl (dalam Kuswarno, 2009: 41 \& 45 ) menjelaskan bahwa untuk menciptakan makna itu harus ada kerjasama antara "aku" dengan dunia di luar "aku", karena walaupun Husserl meyakini betul bahwa proses intuitif reflektif terjadi karena faktor ego dan super ego, dia tidak menolak sama sekali faktor intersubjektif yang juga berperan besar dalam pembentukan makna.

Bagaimana Penulis Sunda memaknai keberadaannya dalam dunia kepenulisan tergantung masing-masing melihat dirinya, pengalaman dengan lingkungannya dan posisi dirinya di lingkungan tersebut. Setiap individu akan memaknai keterlibatan mereka secara berbeda. Husserl (dalam Kuswarno, 2009: 45) menjelaskan bahwa makna yang kita berikan terhadap suatu objek dipengaruhi oleh empati yang kita miliki terhadap orang lain, karena kita cenderung membandingkan pengalaman kita dengan pengalaman milik orang lain. Oleh karenanya faktor intersubyektif juga berperan besar dalam pembentukan makna.

Makna yang terlihat pada diri para Penulis Sunda sebagai Pelestari Budaya Sunda, terdiri dari tiga makna, yaitu diri sebagai pemelihara Bahasa Sunda, yang dirasakan oleh Us Tiarsa, Usep Romli, Taufik Faturohman dan Dadan Sutisna; kemudian diri sebagai mediator, tersirat 
pada Aam Amilia dan Aan Merdeka Permana; serta para penulis yang memaknai diri yang mengenalkan Budaya Sunda lebih luas, yaitu Eddy D. Iskandar dan Hawe Setiawan.

Munculnya makna peran diri para informan Penulis Sunda, tidak terlepas dari interaksi yang mereka jalani dengan diri maupun lingkungannya yang dilakukan secara terus menerus. Dalam posisinya sebagai penyampai pesan, para Penulis Sunda memaknai keberadaannya berdasarkan proses pemahaman terhadap aktifitas yang dilakukannya berdasarkan motif-motif yang menyertainya.

Meski demikian, kaitan antara motif dan makna diri mereka tidak bisa dikotakkotakkan hubungan sebab dan akibatnya, karena makna diri dan motif saling berkesinambungan sehingga tidak dapat diklasifikasikan sebab atau akibatnya. Seperti yang dikatakan Mulyana (2004: 147) bahwa prinsip tentang sifat hubungan dalam dan mengenai realitas pada perspektif subyektif berlaku semua entitas secara simultan saling mempengaruhi sehingga peneliti tidak mungkin membedakan sebab dari akibat.

Schutz (dalam Basrowi dan Sukidin, 2002: 40) menjelaskan bahwa cara kita mengkonstruksikan makna di luar arus utama pengalaman ialah melalui proses tipifikasi. Hubungan-hubungan makna diorganisir secara bersama melalui proses tipifikasi menjadi apa yang disebut dengan stock of knowledge Masih menurut Schutz, manusia adalah mahluk sosial, akibatnya, kesadaran akan kehidupan sehari-hari adalah sebuah kesadaran sosial. Dunia individu merupakan sebuah dunia intersubjektif dengan makna beragam dan rasa ketermasukan dalam kelompok. Melalui proses tipifikasi diri, manusia belajar menyesuaikan diri ke dalam dunia yang lebih luas, dengan melihat pada diri sendiri sebagai orang yang memainkan peran dalam situasi tipikal. Jumlah hubungan sosial tersebut membentuk totalitas masyarakat. Dalam kehidupan bermasyarakat, individu dapat memakai simbol-simbol yang diwarisinya untuk memberi makna pada tingkah lakunya sendiri. Jadi, sebuah pandangan deskriptif atau interpretif tentang tindakan sosial dapat diterima hanya jika tampak masuk akal bagi pelaku sosial yang relevan (Basrowi \& Sukidin, 2002: 41).

Berdasarkan upaya yang telah dilakukan oleh para Penulis Sunda dalam melestarikan Budaya Sunda, maka peneliti mengelompokkan para informan ke dalam dua kategori tipifikasi, yaitu sebagai Pewaris Budaya Sunda dan sebagai Pengembang Budaya Sunda. Para penulis yang dikategorikan sebagai Pewaris Budaya Sunda adalah mereka yang melakukan 
upaya pelestarian Budaya Sunda melalui cara yang umum atau biasa dilakukan sebagian besar Penulis Sunda. Dengan kata lain, upaya yang dilakukan relatif statis. Sedangkan yang dikategorikan sebagai Pengembang Budaya Sunda adalah mereka yang melestarikan Budaya Sunda dengan melahirkan inovasi dalam pelaksanaannya.

Penulis Sunda yang diklasifikasikan sebagai Pewaris Budaya Sunda yaitu Us Tiarsa, Usep Romli, Aam Amilia dan Aan Merdeka Permana. Penempatan empat informan sebagai Pewaris Budaya Sunda didasarkan pada kiprah mereka selama ini sebagai Penulis Sunda yang konsisten melestarikan Budaya Sunda lewat tulisan tanpa dibarengi upaya lainnya untuk melahirkan suatu inovasi.

Sedangkan Penulis Sunda yang diklasifikasikan sebagai Pengembang Budaya Sunda adalah Eddy D. Iskandar, Taufik Faturohman, Hawe Setiawan dan Dadan Sutisna. Alasannya, selain berupaya melestarikan Budaya Sunda melalui tulisan, juga ada inovasi atau upaya lain yang dilakukan. Misalnya Eddy D. Iskandar dengan menulis skenario beberapa film si Kabayan dalam konteks kesundaan yang menasional. Kemudian Taufik Faturohman, melakukan inovasi dengan memadukan sulap dan dongeng Sunda, yang biasanya dikemas secara humor. Selain itu, Penulis Sunda yang akrab disapa Pak Haji ini juga sebagai pengisi acara di I Radio Bandung, yang dalam pengemasannya disampaikan dengan humor. Pak Haji juga secara rutin menulis kolom Mang Ohle, setiap minggu, dalam kemasan humor, yang mengangkat tema-tema aktual.

Hawe Setiawan juga melakukan inovasi dalam kepenulisan Sunda, dengan berupaya mengangkat Budaya Sunda ke ranah yang lebih global, yaitu internasional, yang ia wujudkan dengan menulis tentang kesundaan dalam Bahasa Inggis, yang dimuatnya dalam situs blog miliknya, yaitu http: //Sundanesecorner.org.

Lantas yang terakhir, yaitu Dadan Sutisna, melakukan inovasi dalam kepenulisan Sunda dengan memasukkan unsur-unsur teknologi ke dalam tema-tema tulisannya, untuk memperkaya tema-tema yang sudah ada. Hal tersebut pernah ia tuangkan dalam buku novel untuk anakanak berjudul Rasiah Kodeu Biner dan beberapa puisinya. Dengan kemampuan teknologi informasi yang dikuasainya, Dadan pun sedang berupaya untuk membuat software atau program kamus digital berbahasa Sunda yang bertujuan untuk memudahkan pencarian kata yang sesuai digunakan dalam tulisan.

\subsubsection{Proses Penyampaian Pesan Penulis} Sunda 
Menurut George Ritzer (2004, dalam Bungin, 2008: 81), tindakan manusia tidak sepenuhnya ditentukan oleh norma-norma, kebiasaan-kebiasaan, nilai-nilai dan sebagainya, karena manusia adalah aktor yang kreatif dari realitas sosialnya. Selanjutnya, manusia secara kreatif mengembangkan diri melalui respon terhadap stimulus dalam dunia kognitifnya. Tulisan merupakan realitas subyektif yang terbentuk sebagai proses penyerapan kembali realitas obyektif dan simbolis ke dalam individu melalui proses internalisasi.

Dalam kaitannya dengan penelitian ini, Penulis Sunda sebagai entitas yang memaknai realitas dari perspektif subyektifnya, merepresentasikan makna dirinya ke dalam tulisan berdasarkan motifmotif yang menyertainya untuk dipahami dan dimaknai oleh pembacanya yang akhirnya merefleksikan identitas dirinya.

Dalam penyampaian pesannya, Penulis Sunda menjalani suatu proses mulai dari awal hingga pesan tersebut jadi dan siap didistribusikan kepada pembacanya. Terdapat delapan unsur yang dapat mewakili proses tersebut, yaitu penggalian ide, pemilihan tema dan perancangan pesan yang terbagi ke dalam pemilihan jenis tulisan, pendalaman materi tulisan, cara menuliskan ide, tanggung jawab moral tulisan yang dihasilkan, keterlibatan pengalaman pribadi dalam tulisan dan pemilihan media untuk menyampaikan tulisan

Untuk penggalian ide, penulis memperolehnya dengan sengaja dan tidak sengaja. Sengaja, jika dilakukan dengan mengamati peristiwa aktual yang terjadi atau membaca situasi diri dan lingkungannya. Secara tidak sengaja, jika ide-ide tersebut muncul dengan sendirinya ketika menggali satu persoalan, atau ketika berhadapan dengan suatu peristiwa yang menarik perhatiannya, yang diperolehnya dari kejadian sehari-hari atau lewat buku dan film.

Dalam pemilihan tema, para informan mengungkapkannya secara beragam. Setelah diperoleh tema, kemudian perancangan pesan. Tidak semua informan melakukan perancangan pesan. Kemudian untuk melengkapi data dan fakta yang dibutuhkan dalam tulisan, Penulis Sunda melakukan tiga cara utama, yaitu investigasi langsung, observasi dan mengandalkan referensi dari buku atau sumber tertulis yang dipadukan dengan pengalaman batin untuk menuliskannya.

Dalam setiap tulisan yang dihasilkan, ada tanggung jawab moral yang dituangkan, meskipun hanya tersirat. Tanggung jawab moral yang disampaikan para Penulis Sunda beragam, bergantung pada pemahaman dan pemaknaan mereka terhadap realitas dan penempatan dirinya dalam realitas tersebut. 
Sebagian besar informan Penulis Sunda tidak menjadikan pengalaman pribadi sebagai sumber utama tulisannya. Mereka melakukan perenungan terhadap stimulusstimulus yang diterimanya, untuk kemudian direfleksikan menjadi tulisan setelah melalui proses internalisasi. Ini sesuai dengan konsep fenomenologi Husserl, yang mengutamakan pemahaman berdasarkan perenungan yang dilakukan secara intersubjektifitas dengan dirinya sendiri. Penulis Sunda terkadang melibatkan karakter pribadi dalam tulisannya, terutama

\section{SIMPULAN DAN SARAN}

\section{Simpulan}

1. Motif para informan sebagai Pelestari Budaya Sunda, secara umum karena adanya idealisme yang didasari oleh rasa cinta dan bangga sebagai orang Sunda, sehingga muncul suatu panggilan jiwa untuk melestarikan Budaya Sunda dengan caranya sendiri sebagai seorang penulis. Motif Penulis Sunda sebagai Pelestari Budaya terbagi dua ke dalam aspek pendorong (because motives) dan aspek harapan (in order to motives). Aspek pendorong terdiri dari aspek ekstrinsik dan aspek intrinsik.

Aspek pendorong ekstrinsik Penulis Sunda sebagai Pelestari Budaya adalah kondisi lingkungan keluarga, pergaulan dengan penulis/ pengarang terhadap cara pandang tokoh utama terhadap realitas yang dihadapinya.

Kemudian setelah tulisan jadi, maka penulis melakukan pemilihan media untuk menyampaikan tulisan yang dibuatnya. Tapi sebagian besar justru prosesnya terbalik. Bukan memilih media setelah menyelesaikan tulisan, tetapi, membuat tulisan yang disesuaikan dengan karakter media yang akan dituju. Sebagian besar informan menjadi penulis tetap rubrik di beberapa media cetak lokal berbahasa Sunda dan Indonesia.

Sunda, menonton sandiwara rakyat, mendengarkan dongeng Sunda dan menang lomba mengarang. Sementara, aspek pendorong intrinsik informan sebagai Penulis Sunda terdiri dari: panggilan jiwa, bakat, keterbatasan keterampilan sebagai perempuan, ingin mengenalkan sejarah Sunda, ingin mengenalkan Sunda lebih luas dan ingin meniru pendongeng.

Sementara, pada aspek harapan, para penulis Sunda berharap agar Bahasa Sunda terpelihara keberadaannya, Budaya Sunda dikenal luas dan Sejarah Sunda diketahui dan diakui.

2. Makna diri Penulis Sunda sebagai Pelestari Budaya terbagi ke dalam dua 
tipe, yaitu diri sebagai Pewaris Budaya Sunda dan diri sebagai Pengembang Budaya Sunda. Sebagai Pewaris Budaya Sunda, upaya pelestarian yang dilakukan penulis cenderung hanya melalui satu saluran, yaitu tulisan. Sedangkan sebagai Pengembang Budaya Sunda, para penulis melakukan upaya lain selain melalui media cetak, misalnya melalui pertunjukkan, film, pengembangan tema, pembuatan software Bahasa Sunda dan pemanfaatkan jaringan internet untuk menyalurkan tulisannya di blog atau website.

3. Proses penyampaian pesan Penulis Sunda sebagai pelestari budaya, dilakukan melalui tahapan-tahapan penggalian ide, pemilihan tema dan proses perancangan pesan, yang terdiri dari jenis tulisan yang dipilih, pendalaman materi (investigasi, observasi dan referensi), cara menuliskan ide, tanggung jawab moral tulisan yang dihasilkan, keterlibatan pengalaman pribadi dalam penulisan dan pemilihan media untuk menyampaikan pesan. Penyampaian pesan Penulis Sunda sebagai Pelestari Budaya dilakukan sesuai dengan kebiasaan dan kemampuan mereka untuk menuangkan pikiran dan perasaan tentang realitas kesundaan yang dialaminya ke dalam bentuk yang mereka anggap sesuai dan nyaman untuk menjalaninya. Bisa dalam bentuk fiksi, nonfiksi, bahkan keduanya.

\section{SARAN}

1. Kajian tentang penulis Sunda dapat dilakukan dengan berbagai perspektif atau metode penelitian. Misalnya melakukan penelitian kualitatif dengan pendekatan metode studi kasus, etnografi atau lainnya mengenai keunikan individu Penulis Sunda. Sedangkan untuk pendekatan secara metode kuantitatif dapat dilakukan melalui cara menguji konsep-konsep teoritis yang berhubungan dengan penelitian mengenai Penulis Sunda.

2. Keterampilan menulis yang dimiliki informan tidak lepas dari pengaruh kebiasaan membaca buku yang dapat memberikan dampak luas bagi masyarakat. Perlu lebih banyak taman bacaan atau perpustakaan yang menyediakan bacaan, terutama tentang kesundaan.

3. Penulis Sunda diharapkan mulai terbiasa mendokumentasikan setiap karya yang dihasilkannya supaya mudah diakses dan 
budaya Sunda bisa diwariskan pada generasi selanjutnya.

4. Perlu adanya campur tangan pemerintah daerah untuk mendukung dunia kepenulisan Sunda dalam bentuk lebih nyata, misalnya apresiasi dalam bentuk materi dan materiil, dengan memberikan bantuan subsidi untuk honor bagi para Penulis Sunda yang menulis di media massa Sunda, sehingga merangsang para penulis lebih banyak berkarya dalam Bahasa Sunda, sehingga lebih banyak

\section{DAFTAR PUSTAKA}

Alwasilah, A. Chaedar. 2006. Pokoknya Sunda: Interpretasi untuk Aksi. Bandung: Kiblat.

Basrowi \& Sukidin. 2002. Metode Penelitian Kualitatif; Perspektif Mikro. Surabaya: Insan Cendikia.

Bungin, M. Burhan. 2007. Penelitian Kualitatif. Jakarta: Kencana Prenada.

Budhisantoso, S. 1990. Kondisi dan Masalah Budaya Sunda Dewasa Ini. Jakarta: Depdikbud

DeVito, Joseph A. 1989. The Interpersonal Communication Book. New York: Harper \& Row.

Effendy, Onong Uchjana. 1993. Ilmu, Teori dan Filsafat Komunikasi. Bandung: Citra Aditya Bakti lagi penulis yang berperan sebagai Pewaris dan Pengembang Budaya Sunda.

5. Hasil karya Penulis Sunda merupakan aset warisan bangsa yang perlu dilestarikan dengan cara didokumentasikan dalam satu tempat khusus. Untuk itu dibutuhkan adanya satu tempat khusus yang bisa menyimpan hasil karya para Penulis Sunda agar hasil karyanya dapat didokumentasikan dengan baik untuk disampaikan pada generasi berikutnya agar mata rantai pelestariannya tidak hilang.

2007. Ilmu Komunikasi, Teori dan Praktek Bandung: Rosdakarya

Garna, Judistira K. 2008. Budaya Sunda: Melintasi Waktu Menantang Masa Depan. Cet. ke 3 (revisi). Bandung: Lembaga Penelitian Unpad dan The Judistira Garna Foundation.

Kaye, Michael. 1994. Communication Management. Sidney: Prentice Hall. Kuswarno, Engkus. 2009. Fenomenologi. Bandung: Widya Padjadjaran.

Littlejohn, Stephen W.. 2002. Theories of Human Communication, Belmont: California.

Lubis, A. Hamid Hasan. 1993. Analisis Wacana Pragmatik. Bandung: Angkasa. 
Moleong, Lexy J. 2006. Metodologi Penelitian Kualitatif. Bandung:

Remaja Rosdakarya. 
